\title{
ANÁLISE DA POLÍTICA URBANA HABITACIONAL BRASILEIRA DA ÚLTIMA DÉCADA
}

\author{
Leda Buonfiglio ${ }^{1}$
}

Resumo: O presente artigo retrata a produção da política urbana habitacional brasileira na última década (de 2005 a 2015). Para tanto, é preciso situar as escalas da política urbana no arranjo federativo existente, tendo como pano de fundo o debate da descentralização de políticas públicas sociais do Estado Brasileiro. Recupera-se aqui a conjuntura política da construção do Sistema Nacional de Habitação de Interesse Social (SNHIS) junto a seu Fundo homônimo (FNHIS) pela Lei Federal $\mathrm{n}^{\circ} 11.124$, de 2005, alçando a política urbana a um novo pacto federativo. O Programa de Aceleração do Crescimento (PAC) e o Programa Minha Casa, Minha Vida (MCMV), que têm início em 2007 e 2009 respectivamente, decretam o fim do SNHIS e alavancam a política urbana a um novo patamar com alocação de recursos maciços que suplantam o FNHIS e se desatrelam da política urbana que se estava estruturando.

Palavras-chave: Arranjo Federativo; Déficit Habitacional; Sistema Nacional de Habitação de Interesse Social (SNHIS); Programa de Aceleração do Crescimento (PAC); Programa Minha Casa, Minha Vida (MCMV)

\section{ANALYSIS OF THE BRAZILIAN URBAN HOUSING POLICY IN THE LAST DECADE}

\begin{abstract}
This article describes the set up of the Brazilian urban housing policy in the last decade (from 2005 to 2015). To this end, one must place the scales of urban policy within the existing federative arrangement, against the backdrop of the debate on decentralization of the Brazilian State's social public policies. Here, the political situation during the setting of the National System of Social Interest Housing (SNHIS) with its near-namesake Fund (FNHIS) through Federal Law 11124 of 2005 is recovered, moving the urban policy up to a new federative agreement. The Growth Acceleration Program (PAC) and My Home, My Life (MCMV), which respectively start in 2007 and 2009, put an end to SNHIS and move the urban policy to a new level, with a massive allocation of funds which outdoes FNHIS and are cut off from the urban policy then being structured.

Key words: Federative arrangement; Housing shortage; National System of Social Interest Housing (SNHIS); Growth Acceleration Program (PAC); My Home, My Life Program (MCMV)
\end{abstract}

\footnotetext{
${ }^{1}$ Professora colaboradora do Programa de Pós Graduação em Geografia da Universidade Federal do Rio Grande (FURG), bolsista do Programa Nacional de Pós Doutorado (PNPD/ CAPES)
} 


\section{ANÁLISIS DE LA POLÍTICA URBANA HABITACIONAL DEL BRASIL EN LA ÚLTIMA DÉCADA}

Resumen: El presente artículo retrata la producción de la política urbana habitacional brasileña de la última década (de 2005 hasta 2015). Para ello, es preciso situar las escalas de la política urbana en la organización federal existente, teniendo como plano de fondo el debate de la descentralización de las políticas públicas sociales del Estado brasilero. Aquí, se recupera la coyuntura política de la construcción del Sistema Nacional de Habitación de Interés Social, (SNHIS por sus siglas en portugués) junto con su fondo homónimo, (FNHIS por sus siglas en portugués) por la ley federal $\mathrm{n}^{\circ} 11.124$ de 2005 , alcanzando la política urbana un nuevo pacto federativo. El Programa de Aceleración del Crescimiento (PAC) y el Programa Minha Casa, Minha Vida (MCMV) que inicia en 2007 y 2009 respectivamente, decretan el fin del SNHIS e impulsan la política urbana hacia un nuevo escalón con la dirección de grandes recursos que suplantan al FNHIS, y se desarticula la política urbana que se estaba estructurando.

Palabras Clave: Organización Federativa; Déficit Habitacional; Sistema Nacional de Interés Social (SNHIS); Programa de Aceleración del Crecimiento (PAC); Programa Minha Casa Minha Vida (MCMV)

\section{INTRODUÇÃO: NOTAS SOBRE AS ESCALAS DA POLÍTICA URBANA HABITACIONAL}

As escalas geográficas são construídas socialmente e não fixadas naturalmente por escolhas aleatórias ou espontâneas. Como construção social, a escala é uma instância da ação política que evidencia relações e práticas de poder, servindo mesmo como instrumento a ser mobilizado nas relações de poder dependendo dos jogos e conflitos de interesse (HARVEY, 2004; SMITH $^{2}$; NASCIMENTO DOS SANTOS, 2011). No escopo da política pública e, portanto, na esteira da ação estatal, as escalas são sinônimo de esferas institucionais, isto é, funcionam como níveis de regulação da política (a serem manejadas, manipuladas e articuladas):

As noções (de níveis) tradicionalmente associadas à ideia de escala (tanto as já consagradas e não raro cristalizadas por reificações, como local, regional, nacional e global, quanto àquelas vinculadas à ordem estatal federalista) são então transformadas em marcos referenciais que alicerçam complexos jogos e processos que fundam novas escalas, ao mesmo tempo em que ressignificam, refuncionalizam, anulam ou ignoram estas "antigas". (...) Tais esferas, ao se constituírem como planos onde são alocados poderes, atribuições e compromissos acabam também se transformando em mecanismo organizador de disputas, embates e alianças que constituem os jogos e processos políticos. (NASCIMENTO Dos Santos, 2011, p.124-125).

${ }^{2}$ Smith (apud VAINER, 2002). 
Na política urbana e habitacional brasileira da última década, duas escalas geográficas se destacam: a municipal e a federal. Tais escalas operacionais "cristalizam" esferas institucionais, porque já estabelecidas historicamente, revelando estratégias de dominação e poder, já que são o "resultado e instrumento de territorializações dos grupos dominantes" (NASCIMENTO DOS SANTOS, 2011, p. 130). Mesmo que concebidas como arenas de lutas (ficando abertas aos embates políticos e constituindo o espaço em que novos agentes sociais têm se inserido), não se pode escapar a elas como marco regulatório. Para exemplificar, o autor argumenta que

historicamente o local foi transformado em municipal [e não o contrário] através da construção de um aparato/esfera institucional que circunscrevesse espacialmente os "mandonismos locais" e "coronelismos locais" e atendesse aos seus interesses, possibilitando assim conferir longevidade à elites dominantes nesta escala. (NASCIMENTO Dos Santos, 2011, p.132-133).

Se o município emerge e representa o espaço por excelência da intervenção política, onde a mobilização e pressão social recaem sobre os governos locais, o nacional segue sendo "arena privilegiada de constituição, enfrentamento e concertação de interesses e um construto histórico, sociopolítico e econômico de alinhamento político mínimo dos projetos em disputa" (NASCIMENTO DOS SANTOS, 2011).

A Nova Constituição de 1988 culminou com a definição de bases federativas do Estado brasileiro, fazendo com que estados e municípios passassem a ser, de fato, entes politicamente autônomos, cujas competências são sobrepostas e concorrentes no atendimento de políticas sociais:

Os constituintes de 1988 optaram pelo formato das competências concorrentes para a maior parte das políticas sociais brasileiras. (...) Assim, qualquer ente federativo estava constitucionalmente autorizado a implementar programas nas áreas de saúde, educação, assistência social, habitação e saneamento. Simetricamente, nenhum ente federativo estava constitucionalmente obrigado a implementar programas nestas áreas. (BONDUKI, 2014, p. 294).

Essa sobreposição das escalas geográficas e esferas administrativas na política pública traz, frequentemente, a percepção de uma desarticulação a ser superada entre os agentes dos supracitados níveis. Contudo, seu entrelaçamento apresenta uma forma de articulação em um modus operandi que é interno ao federalismo do tipo brasileiro, como atesta Brandão (2014, p. 218): “o modo peculiar de relacionamento estabelecido historicamente entre os poderes 
central, regional e local e o próprio debate dessas questões no Brasil tornou-se confuso, desorganizado e pouco conclusivo".

Essa confusão e desorganização são já produto do jogo de determinações oscilantes e alternâncias de escalas de poder que, para a Geografia Política, traduzem-se em embates centrais do poder territorializado.

Tentar-se-á explicar esse processo, inicialmente, retomando a perspectiva da Geografia Política e, posteriormente, apresentando o debate de autores de outras áreas sobre os contornos do arranjo federativo e da descentralização de políticas públicas sociais do Estado Brasileiro.

Para a Geografia Política, as escalas geográficas, ainda que representativas de relações formais jurídicas e constitucionais, são mais que limites em um mapa dado por entes federativos; são, também, espaços políticos onde relações de poder se materializam. Por essa razão, compreende-se como os diversos países territorializaram suas políticas de Estado em formatos distintos, fundamentadas, de modo geral, no centralismo ou no federalismo, guardadas suas especificidades (CASTRO, 2005).

Iná E. de Castro (2005, p. 165) recorda o arranjo federativo fundador do Estado Republicano Brasileiro: “A República adotou a estrutura federativa como mecanismo de descentralização do poder imperial definindo as três esferas político-administrativas: a federal, a estadual e a municipal". No Brasil, o federalismo acomodou as tensões da necessidade de uma união das diferenças para formar uma unidade. Havia, portanto, uma disfunção entre um formato político administrativo e a manutenção de uma unidade cuja sustentação fora dada pela extensão territorial, desde o Brasil Colônia (CASTRO, 2005) ${ }^{3}$. Deve-se ressaltar que as diferenças encontradas pela extensão territorial brasileira correspondiam a uma "constelação de feitorias" de "extraordinária polivalência cultural, no contexto de enorme heterogeneidade estrutural", como fora resgatado de Celso Furtado ${ }^{4}$.

O Federalismo "enquanto pacto territorializado do poder" pode ser definido como:

convenção sociopolítica que busca coesionar entes não equipotentes econômica e politicamente, procurando forjar um mínimo de coerência de propósitos em determinada escala espacial, definindo e tramando compromissos pactuados, com mínimos patamares de orientação de compartilhamento e corresponsabilidade de destino no curso do processo de desenvolvimento. (BRANDÃO, 2014, p. 213).

\footnotetext{
${ }^{3}$ A unidade que conferia uma identidade nacional fora forjada e a ideologia que a fabricou fora retratada por historiadores, antropólogos e geógrafos brasileiros.

${ }^{4}$ Brandão (2014, p. 217).
} 
Para o caso brasileiro, entretanto, como aponta o autor, há uma especificidade com "a construção de uma escala nacional em contexto de divisão tripartite de poderes republicanos e de estruturação de um complexo regime de federalismo trinitário, em que todos os entes têm autonomia" (BRANDÃO, 2014, p. 214). Essa característica do formato político administrativo brasileiro apresentou, historicamente, um curioso movimento pendular que intercala ora o centralismo autoritário, ora o federalismo investido no mandonismo local. $\mathrm{Ou}$ seja, um arranjo federativo que foi construído sobre pactos entre grupos dominantes, em todas as unidades administrativas da federação (CASTRO, 2005; BRANDÃO, 2014).

Celso Furtado afirmou, décadas atrás, que, no Brasil, a luta pelo federalismo estava "ligada às aspirações de desenvolvimento das distintas áreas do imenso território que o forma" (FURTADO apud BRANDÃO, 2014, p. 217). A despeito dessas aspirações, num determinado período histórico brasileiro, após os governos do regime militar, havia excessiva centralização no processo decisório em escala federal, ineficiência, corrupção e ausência de participação popular. Uma das grandes reivindicações democráticas dos anos 1980, além do próprio fim da ditadura e retorno à democracia, consistia justamente em apontar as virtudes de outro modelo, embasado na descentralização: “Centralização e autoritarismo eram ambos encarados como filhos da ditadura, ao passo que descentralização, democratização do processo decisório e eficiência na gestão pública andariam automaticamente juntas" (ARRETCHE, 2002a, p. 26).

A descentralização, com a gestão local de políticas públicas, colocava-se como oposição aos "vícios e problemas gerados pelas estruturas centralizadas instituídas ao longo do século 20 " e, assim, tornava-se "portadora de expectativas as mais positivas com relação a resultados desejáveis da ação do Estado" (ARRETCHE, 2003, p. 332). A ênfase das políticas governamentais se dirigia para a escala local e para um reforço do municipalismo, como reação política aos 25 anos de centralização federal promovida pelos governos da ditadura militar (LIMONAD, 2013).

Brandão analisa de forma crítica a combinação de, pelo menos, três processos políticos e econômicos durante os anos 1980, que atravessaram e interpuseram as escalas nacionais:

(...) o debate sobre a necessidade de uma repactuação federativa surge no Brasil em um momento histórico paradoxal e eivado de contradições (...), pois três processos distintos se entrecruzaram no curso do processo histórico: os processos de liberalização econômica dos países centrais; o processo de redemocratização brasileiro; e a profunda crise fiscal, financeira e de legitimidade do Estado. A discussão sobre o caráter do federalismo brasileiro e a necessidade de repactuação de suas relações ressurgiu em contexto de um 
ambiente político e econômico inóspito, portanto em conjuntura pouco adequada para enfrentar seus impasses históricos. (BRANDÃO, 2014, p. 218).

Assim, o contexto político da década de 1980 apresentou profundas contradições e um intenso debate sobre o Estado Brasileiro. A crise do federalismo era já uma dimensão da crise do Estado, cujo formato descentralizado encaixava-se na política neoliberal de modo que a descentralização era antes, fiscal (FIORI apud BRANDÃO, 2014). No texto da nova Constituinte (de 1988) ${ }^{5}$ destacam-se os mecanismos fiscais da descentralização política pelo repasse de recursos como "transferências constitucionais obrigatórias da União para os estados, municípios e regiões" no que Arretche (2004, p. 18) sinalizou como a “descentralização de receita, mas não encargos”. O resultado desse arranjo - mais que pacto entre os entes federados é a ausência de mecanismos institucionais que estimulem a cooperação intergovernamental como uma força centrífuga e desagregadora, já que, em tese, as garantias constitucionais do Estado federativo permitem que os governos locais - com autonomia política e fiscal - estabeleçam sua própria agenda na área social, independentemente da agenda do Executivo federal (ARRETCHE, 2004; BRANDÃO, 2014; ISMAEL, 2014).

Como o processo denominado descentralização das políticas sociais corresponde genericamente à "institucionalização no plano local de condições técnicas para a implementação de tarefas de gestão de políticas sociais", Arretche $(1996$, p. 1) advertia que a União não podia se retirar de cena deixando que os municípios passassem a assumir espontaneamente tais competências de gestão. Para tanto, seria necessária uma ação política deliberada, no sentido de criação de "estratégias de indução eficientemente desenhadas para delegar a outro nível de governo a responsabilidade pela gestão" (ARRETCHE, 1996, p. 1). A autora, portanto, afirma que a "ação do governo federal permanece necessária para viabilizar patamares básicos de produção de serviços sociais" (ARRETCHE, 2004, p. 19). Em um cenário otimista, em que as agendas municipais dos governos locais estivessem comprometidas com as políticas sociais, de fato, poder-se-ia deixar tal atribuição apenas à autonomia desse ente, considerando, porém, que:

Não há nenhuma garantia intrínseca à autonomia dos governos locais que os torne responsáveis, comprometidos com as necessidades dos cidadãos e

\footnotetext{
${ }^{5}$ Salienta-se que foi a Constituição Federal de 1946 que deu início à prática de transferências constitucionais da União para a solução de problemas regionais, no caso para o Nordeste (ISMAEL, 2014).
} 
determinados a administrar com eficiência. (...) Não há dúvida de que há governos locais responsáveis e comprometidos com a eficiência da gestão e $\mathrm{o}$ atendimento das demandas dos cidadãos por motivos programáticos e/ou da qualidade moral de seus governantes. Mas, a responsabilidade dos governos locais - e, por consequência, a qualidade de um sistema assentado sobre a descentralização - somente poderia ser garantida exclusivamente com base no programa dos partidos e na qualidade moral dos governantes se fosse possível garantir que governantes deste tipo fossem a maioria. (ARRETCHE, 2003, p. 334).

Portanto, a autonomia decorrente da descentralização dos governos locais não garante a qualidade ou o comprometimento da política implantada. A autonomia local, por sua vez, cria "oportunidades institucionais para que os governantes implementem decisões de acordo com suas próprias preferências, as quais não são necessariamente compatíveis com o interesse público e o bem-estar da população" (ARRETCHE, 2003, p. 335). De acordo com o modelo instituído de descentralização político-financeira de estados e municípios (com a distribuição de competências entre todos os entes federados), a promoção de políticas públicas fica comprometida já que produz "superposição de ações; desigualdades territoriais na provisão de serviços; e mínimos denominadores comuns nas políticas nacionais" (ARRETCHE, 2004, p. 22).

A autora (ARRETCHE, 1996; 2002a; 2002b) analisou o extensivo programa de descentralização das políticas sociais que se implementou no final dos anos 1990 com a redefinição de atribuições e competências, caracterizando uma mudança no padrão, até então centralizado, do Sistema de Proteção Social Brasileiro (SPSB), tal como constituído ao longo dos anos 1960 e $1970^{6}$. Em ritmo lento e com variações no alcance do fenômeno para cada uma das políticas sociais, a descentralização representava, segundo a autora, um processo inédito de transferência paulatina de um conjunto significativo de atribuições de gestão que, dependendo de cada política, tomava a forma da estadualização e/ou municipalização. Em algumas políticas sociais, como a educacional e a de saúde, os programas de descentralização tinham como meta a municipalização da gestão de determinadas tarefas, ao passo que na política habitacional, a perspectiva era de que se constituíssem sistemas estaduais de prestação de serviços. Pelo menos duas ações identificavam a descentralização da política habitacional para a escala estadual: a criação de instâncias colegiadas estaduais para a alocação do FGTS e a emergência de sistemas estaduais de habitação.

6 Essas políticas sociais correspondiam à educação fundamental, assistência social, saúde, saneamento e habitação popular, exceção à previdência social. 
Atualmente, pode-se falar de um esmaecimento na escala estadual que não engendra nem promove diretamente processos, mas replica uma rede de apoio como uma "esfera intermediária de poder" (BRANDÃO, 2014, p. 221). Isto é, ela interfere na produção da política, mas de forma indireta, como a exemplo, na complementação do aporte de recursos para municípios em algumas modalidades dentro de programas federais.

Bonduki (2014) também analisou o processo de descentralização da política habitacional com programas municipais que, do ponto de vista político, fez surgir um conjunto de experiências criativas de habitação social, acentuado em um quadro de ajuste fiscal e, portanto, poucos recursos municipais, em gestões municipais de vanguarda. Por força das circunstâncias, municípios e estados tiveram de elaborar soluções e enfrentar de forma autônoma a questão habitacional, o que, positivamente, fez emergir, ainda que de forma pontual e fragmentária, um amplo conjunto de experiências criativas com habitação social (BONDUKI, 2014).

De toda forma, seja com maior ênfase na escala estadual (em alguns estados), seja com maior ênfase na escala municipal, o período marcou maior autonomia desses entes e fez surgir concepções e modelos distintos que seriam retomados para o enquadramento da política habitacional na escala federal, anos depois.

\section{HIS, SNHIS \& FNHIS: O COMEÇO E O FIM DE UMA POLÍTICA URBANA NACIONAL}

As limitações quanto às estratégias de indução e de coordenação nacional das políticas públicas sociais, no arranjo federativo trinitário existente, implicam a preocupação dos "mínimos denominadores comuns nas políticas nacionais" (ARRETCHE, 2004, p. 22 ). Como combinar o arranjo de forma que todos os entes federados de fato estabeleçam um verdadeiro pacto de atribuições e responsabilidades compartilhadas, e que sejam convertidos em produtores de políticas públicas e promotores de melhorias reais nas condições de vida da sociedade brasileira? Simplificando a questão: como articular todos os entes, descentralizando de fato a gestão da política urbana e habitacional a partir (e para além) da descentralização de recursos? Essa indagação encontrava eco nas preocupações dos articuladores e gestores da política urbana quando nos primeiros anos do Ministério das Cidades.

A resposta encontrada estava na proposta de montagem do Sistema Nacional de Habitação de Interesse Social, o SNHIS, "um novo desenho institucional descentralizado" para a política urbana que reestruturava o arranjo federativo, criando uma "base que permitia 
articular os três entes da federação" (BONDUKI, 2014, p. 306), que consistia na adesão dos entes federados para acessar os recursos federais de um Fundo Nacional, o FNHIS, de forma descentralizada, num modelo de transferência fundo a fundo (do Fundo Nacional aos fundos municipais). Antes de dar prosseguimento ao alcance desse Sistema instituído e à política de HIS, cabe recordar o papel histórico e a expectativa popular quanto à necessidade de um Fundo específico e nacional para a habitação popular.

Em 1992, foi apresentado ao Legislativo Federal o primeiro Projeto de Lei de iniciativa popular, então nomeado Fundo Nacional de Moradia Popular (PL 1992). Esse Projeto de Lei contou com um milhão e duzentas mil assinaturas, tendo sido aguardado por 13 anos por militantes do Fórum Nacional de Reforma Urbana (FNRU) e pelos movimentos populares, quando, em 16 de junho de 2005, com a tramitação no Congresso Nacional, foi aprovado pela Câmara Federal e sancionado pelo presidente da República como Fundo Nacional de Habitação Interesse Social (FNHIS), pela Lei Federal n ${ }^{\circ} 11.124$, de 2005 . Havia expectativa também da parte de seus idealizadores e dos gestores, à época, como sendo o fundo indispensável para a sustentação da política habitacional federal para baixa renda (BUONFIGLIO, 2007).

Quanto a seu formato, fora espelhado nos moldes do Sistema Unificado de Saúde (SUS) cujo funcionamento cooperativo pretendia “(...) buscar de forma integrada, mas considerando as particularidades regionais e locais, soluções para a carência habitacional" que, à época da criação do sistema, atingia quase 7 milhões de moradias (MINISTÉRIO DAS CIDADES, RELATÓRIO DE GESTÃO, 2013, p. 8). O modelo do Fundo, de fato, buscava somar esforços entre os entes federados, pois sua integração fora estruturada de modo a redistribuir níveis de competência e deliberação no âmbito da gestão da política, delegando poder e autonomia (não apenas descentralizar recursos) aos municípios e "estimulando a participação de todos os agentes públicos e privados, da sociedade organizada, dos setores técnicos e acadêmicos (MINISTÉRIO DAS CIDADES, RELATÓRIO DE GESTÃO, 2013)”.

Para tanto, era necessário que os municípios e estados instituíssem um "tripé" sustentado por: fundos, conselhos e planos locais de habitação, a saber: um Conselho Municipal de Habitação, um Fundo Municipal de Habitação e um Plano Local de Habitação de Interesse Social (PLHIS). 
O Conselho Nacional das Cidades também recomendou, a partir de duas Resoluções, sobre a criação de Conselhos Municipais ${ }^{7}$ e a elaboração de outros Planos Locais, além do de Habitação de Interesse Social (PLHIS); de Saneamento Básico e de Mobilidade Urbana ${ }^{8}$.

Em tese, o Conselho Local, o Fundo Local e o PLHIS reforçariam a necessidade do município de dispor, em sua estrutura institucional, de uma Secretaria, um Departamento ou órgão de Habitação capaz de fazer frente às demandas do governo federal. De fato, para além do tripé que foi estabelecido como pré-requisitos do SNHIS, havia na concepção original do SNH (no escopo do projeto Moradia) mais uma condição sine qua non: os entes deveriam constituir um órgão executivo com competência para desenvolver e implantar programas e projetos (BONDUKI, 2014).

Do ponto de vista da capacidade institucional (e também política), partia-se de duas lógicas para lidar com a realidade dos municípios; os "maduros" que "pudessem andar com suas próprias pernas" e que conseguissem uma adesão integral ao sistema, e aqueles que continuariam no "caminho tradicional", por expedientes comuns; isto é, apresentando projetos (pautados em normativas nacionais) "para serem aprovados nas instâncias sob controle do nível federal” (BONDUKI, 2013, p. 35).

Cumpre salientar que a instituição de Conselhos e Planos Locais nos municípios tem como pressuposto a democracia participativa, presente na Constituição Brasileira, e a gestão democrática, diretriz geral da política urbana incorporada pelo Estatuto das Cidades.

$\mathrm{Na}$ concepção original, os PLHIS eram indispensáveis como "fundamento para a tomada de decisões", pois, de fato, os recursos descentralizados seriam destinados de acordo com as estratégias de ação dos planos municipais, garantindo, portanto, uma margem ampla de liberdade municipal para a execução de sua política. Além disso, os PLHIS eram encarados como instrumento de avaliação, nos quais o próprio governo federal se subsidiaria para respaldar, ou não, a adesão do ente ao sistema (BONDUKI, 2013). Portanto, o PLHIS era uma peça importante na concepção do Sistema.

A partir das formulações teóricas de autores (ARRETCHE, 1996, 2002, 2003, 2004; BONDUKI, 2013, 2014; ISMAEL, 2014; BRANDÃO, 2014) podemos enquadrar o SNHIS/FNHIS como a forma de criar "amarras" em um arranjo federativo trinitário que não obriga os entes a participarem da agenda política da União; isto é, era a possibilidade de

\footnotetext{
${ }^{7}$ Resolução Recomendada n ${ }^{\circ}$ 15, de 08 de junho de 2006.

${ }^{8}$ Resolução Recomendada n ${ }^{\circ}$ 61, de 3 de dezembro de 2008.
} 
romper com a tendência verificada de baixo grau de coordenação e indução da escala federal em relação aos demais entes e, portanto, em uma baixa adesão às políticas públicas sociais elaboradas em nível nacional. Ao mesmo tempo, o SNHIS não colocava uma camisa de força pela imposição de programas a serem rebatidos ou replicados de cima, pelo contrário, entrevia a possibilidade de diversas modalidades na produção habitacional: de lotes urbanizados à locação social no meio urbano e arrendamento de unidades no meio rural. Apenas exigia que os municípios se estruturassem para darem conta de suas políticas a serem desenvolvidas autonomamente ${ }^{9}$, uma vez respaldadas pelo Plano Diretor do município.

Da mesma forma, Bonduki (2013) aponta para a ideia original da montagem do Sistema (SNH) pelas duas formas de adesão dos entes federativos: adesão parcial ou adesão integral, explicitando no último caso uma real autonomia no nível da execução de política municipal:

(...) no caso da adesão parcial, os recursos do FNHIS estariam acessíveis mediante a apresentação e aprovação de projetos a serem apoiados, enquanto os entes que obtivessem a adesão integral receberiam recursos para implementar sua política de forma autônoma, por transferência automática ao respectivo fundo, de acordo com os critérios estabelecidos pelo conselho Gestor do Fundo Nacional. (BONDUKI, 2013, p. 36, grifo nosso).

A HIS se desenvolveu na esteira desse processo, estruturada pelo SNHIS/FNHIS, como "guarda-chuva" da política nacional atrelada à produção de uma política ampla e genérica, que enfatizava os princípios e diretrizes de prioridade no atendimento à menor renda e de acesso à terra urbanizada e à habitação digna. Também vale destacar o artigo terceiro da supracitada legislação, que o SNHIS havia sido pensado para "centralizar todos os programas

\footnotetext{
${ }^{9}$ Convém copiar um trecho da Lei Federal $\mathrm{n}^{\circ}$ 11.124, de 2005 (artigo 11), para tal esclarecimento: Art. 11. As aplicações dos recursos do FNHIS serão destinadas a ações vinculadas aos programas de habitação de interesse social que contemplem: (Vide Lei $n^{\circ} 11.888$, de 2008). I - aquisição, construção, conclusão, melhoria, reforma, locação social e arrendamento de unidades habitacionais em áreas urbanas e rurais;II - produção de lotes urbanizados para fins habitacionais;III - urbanização, produção de equipamentos comunitários, regularização fundiária e urbanística de áreas caracterizadas de interesse social; IV - implantação de saneamento básico, infraestrutura e equipamentos urbanos, complementares aos programas habitacionais de interesse social; $\mathrm{V}$ aquisição de materiais para construção, ampliação e reforma de moradias;

VI - recuperação ou produção de imóveis em áreas encortiçadas ou deterioradas, centrais ou periféricas, para fins habitacionais de interesse social;VII - outros programas e intervenções na forma aprovada pelo Conselho Gestor do FNHIS.§ 1o Será admitida a aquisição de terrenos vinculada à implantação de projetos habitacionais. § $20 \mathrm{~A}$ aplicação dos recursos do FNHIS em áreas urbanas deve submeter-se à política de desenvolvimento urbano expressa no plano diretor de que trata o Capítulo III da Lei no 10.257, de 10 de julho de 2001, ou, no caso de Municípios excluídos dessa obrigação legal, em legislação equivalente.
} 
e projetos destinados à habitação de interesse social". Portanto, o SNH foi pensado como mecanismo de coordenação e de indução de cima (esfera federal), mas estruturando e capacitando o poder municipal "abaixo". Na perspectiva de uma efetiva descentralização na execução da política habitacional analisada aqui, pode ser pensado como um verdadeiro pacto entre todos os entes da Federação, na medida em que pensava em "dispor de uma estrutura institucional espelhada", para além da estrutura institucional formal concentrada no Ministério, em aparelhos descentralizados (demais órgãos de governo como Secretarias) e esferas de poder para além daquelas institucionais (com controle social e participação popular) reequilibrando/redistribuindo a força política em todo o arranjo, porque, para além dos entes federados, combinando agentes públicos e privados da sociedade organizada. $\mathrm{O}$ modelo proposto do sistema SNHIS/FNHIS ilustra bem a dimensão do tempo-espaço da política pública porque supera as esferas institucionais e tradicionais de poder, promovendo possibilidades de maior abertura, com diversos agentes sociais, por meio de instâncias colegiadas de poder e de ação política em verdadeiras arenas de lutas.

Contudo, em que pese a adesão municipal ao SNHIS de quase $100 \%$ dos municípios brasileiros, como se pode visualizar no Quadro 1, as exigências para a adesão não foram contempladas de forma esperada, sobretudo quanto à apresentação dos PLHIS em apenas $42 \%$ do conjunto de municípios, isto é, menos que a metade do universo (2.344 municípios). Já a apresentação da Lei para um Fundo Local e para um Conselho Local empatam com 87\%, como aparece no Quadro 01, a seguir.

Quadro 1 - Adesão dos Entes Federados ao SNHIS e Atendimento das Exigências para Adesão ao SNHIS

\begin{tabular}{|l|c|c|c|c|}
\hline \multicolumn{5}{|c|}{ Evolução da adesão dos municípios ao SNHIS } \\
\hline Situação/Data & $31 / 10 / 2012$ & $\%$ & $31 / 12 / 2013$ & $\%$ \\
\hline Adesões municipais ao SNHIS & 5405 & 97,29 & 5425 & 97,5 \\
\hline Adesões de estados e distrito federal ao SNHIS & 27 & 100 & 27 & 100 \\
\hline \multicolumn{2}{|c|}{ Evolução do atendimento das exigências em relação à adesão } \\
\hline Situação/Data & $31 / 12 / 2012$ & $\%$ & $31 / 12 / 2013$ & $\%$ \\
\hline Apresentação Lei Fundo & 4844 & 87,04 & 4846 & 87,07 \\
\hline Apresentação Lei Conselho & 4833 & 86,84 & 4846 & 87,07 \\
\hline $\begin{array}{l}\text { Apresentação do Plano Local de Habitação de } \\
\text { Interesse Social (PLHIS) }\end{array}$ & 1787 & 32,12 & 2344 & 42,12 \\
\hline
\end{tabular}


Fonte: BUONFIGLIO, L. V. (2015).

De resto, muitos desses planos estão parados por problemas de coordenação do processo terceirizado pelo poder público a "especialistas" (seja por empresas de consultorias, seja por universidades), ou foram simplesmente engavetados, seja porque não orientam a política municipal tal qual a estratégia original, seja porque os municípios estão voltados nos últimos anos à produção habitacional maciça.

Não só os planos locais como as demais exigências, a exemplo do Fundo e do Conselho municipais, perderam grande parte de seu sentido original para se tornarem uma obrigação formal, sem que o próprio município compreendesse sua importância como instrumento de gestão. (...) não foi admitida a possibilidade de transferência de recursos federais fundo a fundo para Estados e Municípios cuja adesão integral fosse concedida como previa o Projeto Moradia. O próprio conceito de adesão integral foi descartado. (BONDUKI, 2013, p. 36).

Entre a montagem do Sistema, a partir de 2005, e sua adesão em praticamente todos os mais de 5.000 municípios brasileiros, o SNHIS e o FNHIS foram perdendo força política e espaço, tendo se tornado mais uma diretriz norteadora vaga carimbando o rótulo "de interesse social". Em realidade, entre 2007 e 2010, a HIS passou a ser um "subprograma" locado dentro de um Programa maior que centralizou grande parte dos recursos do Ministério das Cidades, o Programa de Aceleração do Crescimento (PAC 1 e 2), ainda que com intervenções em diversas frentes. De forma coerente com o SNHIS, grande parte dos recursos, em nome da HIS, foi captada para o planejamento na escala municipal com as intervenções "Elaboração de Planos Locais de Habitação" e "Elaboração de estudos e projetos para urbanização"; outras frações foram repartidas entre intervenções pontuais e pouco expressivas, como provisão habitacional, produção de lotes urbanizados, assistência técnica e produção de unidades habitacionais, correspondendo, porém, a uma expressão bem menor tanto nos valores quanto no número de intervenções que aqueles direcionados para a produção habitacional.

Um dos motivos da perda de força política do Sistema foi a questão financeira, conquanto o FNHIS se tornasse "pouco mais do que uma dotação orçamentária" com baixo "potencial de financiamento" (BONDUKI, 2013, p. 36). Como os demais fundos estatais distinto apenas do FGTS que é um fundo público e oneroso - o FNHIS é um fundo vinculado ao orçamento, no caso, alimentado pelo Orçamento Geral da União, estando, portanto, 
suscetível às alterações e reduções orçamentárias submetidas ao veto do Congresso Nacional por meio de Projetos de Lei Orçamentária e Emendas Parlamentares.

Mas, a questão da dotação orçamentária do FNHIS poderia explicar de forma isolada a perda da força política da HIS? Ou a resposta estava em outro lugar?

A resposta estava, de fato, em outro lugar:

Inicialmente, quando o Fundo foi aprovado em 2005, o governo Lula se comprometeu a alocar no fundo anualmente um bilhão de reais, valor considerável à época. Entretanto com a criação do Programa de Aceleração do Crescimento -PAC - especialmente o eixo Urbanização de Assentamento Precários em 2007, e, sobretudo do programa Minha Casa, Minha Vida em 2009, esse valor mostrou-se pouco relevante, uma vez que o governo federal decidiu alocar os recursos não onerosos para os novos programas sem incorporá-los ao FNHIS. Assim, no momento em que o governo federal elevou significativamente o investimento em habitação, sua destinação ficou inteiramente independente das exigências estabelecidas para que os municípios aderissem ao SNHIS. (...) A despeito dos critérios e da estratégia estabelecida no PlanHab, igualmente não incorporado na implementação real da política habitacional, a alocação de recursos do PAC e do MCMV deixou de obedecer critérios que levassem em conta as exigências estabelecidas na Lei 11.124/05. (BONDUKI, 2013, p.36-37).

Não podemos nos deter apenas na análise crítica da conjuntura focando tão somente em um órgão federal, sob o risco de não atingirmos a complexidade com que a política urbana é produzida pelo Estado Brasileiro. Ainda que o Ministério das Cidades seja o órgão por excelência para tratar da questão urbana, as decisões de recursos e financiamentos de importantes volumes estão nas mãos de outros órgãos, como os Ministérios do Planejamento, da Fazenda e a Casa Civil que, por sua vez, estão atrelados à economia nacional e internacional.

\section{NOTAS DA HABITAÇÃO COMO DÉFICIT}

No período contemporâneo, deparamo-nos com o problema social da habitação brasileira a partir de um certo "pragmatismo técnico" (VALENÇA, 2014). O autor se refere à "obsessão, nas últimas duas décadas, em conhecer a natureza e, mais ainda, os números do problema habitacional no país" que, no entanto, “em pouco tem servido para balizar as ações de políticas públicas" (Valença, 2014, p.351).

De fato, um saber técnico institucionalizou-se nos últimos anos no Brasil. Para enxergar o problema é preciso dimensioná-lo, diagnosticá-lo e assim, quantificá-lo. Tal saber 
técnico redunda na aplicação de números que quantificam e estimam o problema habitacional no presente e no futuro. Surge o déficit habitacional brasileiro passível de ser lido, interpretado e manipulável como um dado específico para todo o território nacional ${ }^{10 .}$

Foram diversas metodologias concorrentes para anunciar o tamanho e, até certa medida, a natureza do déficit habitacional brasileiro. A metodologia que passou a ser adotada oficialmente, durante o governo Fernando Henrique Cardoso e perdura até os dias de hoje (com algumas adaptações), é a da Fundação João Pinheiro (FJP) que considera aspectos quantitativos e qualitativos; isto é, dimensiona dois universos de situações problemáticas na condição do habitar.

O primeiro universo é computado por domicílios precários, domicílios com coabitação familiar, domicílios com ônus excessivo em aluguel e domicílios alugados com adensamento excessivo. A solução aqui é dupla porque, além da construção de nova moradia, implica necessariamente a aquisição de novos terrenos, ao menos para as famílias conviventes (coabitação ou adensamento excessivo) e/ou as que vivem de aluguel. Apenas no caso de domicílios precários, não implica necessariamente um novo terreno, caso se possa demolir e construir uma nova habitação no mesmo lugar. No segundo universo estão computados os casos de domicílios com algum tipo de inadequação: fundiária, de serviços de infraestrutura e inexistência de unidade sanitária domiciliar exclusiva, adensamento excessivo em imóveis próprios e cobertura inadequada. Aqui os problemas são mais complexos, porque extrapolam o domicílio pontualmente, atingindo o entorno imediato, o bairro, a rua, uma vez que a solução não é uma nova construção para substituir uma casa precária, mas a efetivação da regularização fundiária da posse em toda a comunidade, bem como a efetivação do acesso às infraestruturas urbanas básicas em todo o bairro. O déficit qualitativo é o maior déficit urbano brasileiro.

A separação da vida privada em cômodos da casa, entre outros critérios de classificação para a unidade familiar, é fundamentada por juízos sociais, econômicos e culturais e que, portanto, não estão isentos de juízos valorativos a partir de um ideal não apenas arquitetônico, mas, sobretudo, social que se foi instituindo e padronizando nas cidades ao longo do tempo (CAPEL, 2005).

${ }^{10}$ Em “A produção capitalista da Casa e da Cidade no Brasil Industrial” Gabriel Bolaffi (in Maricato, 1992) já analisava criticamente a ideia de déficit. 
A partir e para além do déficit quantitativo e qualitativo, novas classificações e critérios surgiram para designar e qualificar os assentamentos urbanos. Uma nova categoria de abrangência nacional foi adotada: os assentamentos precários que correspondem ao "conjunto de assentamentos urbanos inadequados ocupados por moradores de baixa renda". Essa categoria engloba, por sua vez, outras tipologias de assentamentos, como: cortiços, favelas, loteamentos irregulares, conjuntos habitacionais produzidos pelo poder público, etc. (Denaldi, 2013).

Aqui, nota-se que o precário deixa de ser o critério do déficit quantitativo (domicílios sem paredes de alvenaria ou madeira aparelhada) para se transformar numa categoria mais ampla que abarca inúmeras carências e inadequações. A precariedade torna-se, assim, uma síntese $^{11}$, porque amalgama a favela, o cortiço, os conjuntos habitacionais, os loteamentos. A precariedade é, pois, o retrato do Brasil urbano.

$\mathrm{Na}$ análise do discurso, trata-se de um termo com menor risco de estigma social, pois centra sua atenção não na população que o habita (favela - favelado; vila - vileiro; à margem - marginal), mas no lugar em si - objeto da política, objeto de intervenção, e sua designação como lugar precário é já o reconhecimento político de que serviços públicos lhe faltam, sendo, portanto, lugares carentes (e não população carente). Essa estratégia de recurso de linguagem é positiva no sentido de não criminalizar a pobreza, delimitando e objetivando o problema social: o assentamento em si.

Do mesmo modo, é possível contrapô-lo ao conceito de aglomerado subnormal do IBGE, caracterizado por

um conjunto constituído de no mínimo 51 unidades habitacionais (barracos, casas...) carentes, em sua maioria de serviços públicos essenciais, ocupando ou tendo ocupado, até período recente, terreno de propriedade alheia (pública ou particular) e estando dispostas, em geral, de forma desordenada e densa. (IBGE, 2011).

Diversos levantamentos, mapeamentos e sistematização de informações sobre a urbanização sob os mais variados aspectos foram formulados. Cálculos se alteraram ao longo do tempo, com medidas mais sofisticadas de contagem de domicílios, número de favelas e de barracos, áreas irregulares. Nesse sentido, destacam-se as novas metodologias e

\footnotetext{
11 Síntese composta de irregularidade fundiária, ausência de infraestrutura de saneamento ambiental, áreas de risco, insalubridade, áreas mal servidas de serviços de transportes etc.
} 
procedimentos adotados para a realização do Censo de 2010, do IBGE, com o intuito de atualizar e aprimorar a identificação dos aglomerados.

Da mesma forma, o uso e o acesso a imagens de alta resolução (fotos de satélite e fotos aéreas), bem como novas ferramentas de geoprocessamento, permitiram uma lente "anônima", isto é, de aproximação virtual do pesquisador com o objeto de estudo que pudesse captar um retrato brasileiro fidedigno em diversas escalas. É a objetiva (perspectiva crítica e pessimista) sob o prisma do planeta favela ${ }^{12}$.

Essa leitura pragmática produziu uma série de documentos, publicações, fartos materiais que subsidiam políticas públicas, alojando-se na tecnocracia das repartições públicas. Esse saber técnico emprega pesquisadores, estudantes, profissionais de diversas áreas, como um "nicho" de mercado que faz surgir inúmeras empresas de consultorias que pairam ao redor de instituições estatais.

Não se ignora a relevância desses resultados, desse avanço e desse acúmulo. São ferramentas indispensáveis à leitura crítica da realidade e essenciais à formulação de políticas públicas. Apenas se constatam a produção e circulação de um conhecimento cada vez mais técnico e especializado sobre as condições da moradia. Nessa "cientificização" do problema habitacional perde-se a visão do todo, a saber, o espaço geográfico e o tecido social; perde-se a perspectiva de que a habitação é, antes de mais nada, um problema social urbano, como F. Engels (2011) já havia sinalizado, parte estrutural e intrínseca da urbanização capitalista. A crítica reside no fato da perda da análise mais profunda sobre o problema social, do qual a Geografia, a Sociologia e o Urbanismo sempre foram ciências parcelárias e que sempre denunciaram, apontando contradições e conflitos. Tecnicamente estamos "em dia com o déficit” e, sob essa perspectiva, a habitação já foi suficientemente diagnosticada. Politicamente era necessário dar um passo a mais.

DA LEITURA DO DÉFICIT QUANTITATIVO À PRODUÇÃO HABITACIONAL DE ESCALA: O PMCMV

O Programa Minha Casa, Minha Vida (PMCMV), Lei nº 11.977 de 2009, chegou a entrar no sexto ano, tendo lançado oficialmente sua terceira edição em julho de 2014, apontava para a meta ambiciosa de construção de três milhões de unidades a partir de 2015 . Em realidade, o PMCMV estava dividido em dois subprogramas: o Programa Nacional de

\footnotetext{
12 Em alusão à obra de Mike Davis.
} 
Habitação Urbana (PNHU) e o Programa Nacional de Habitação Rural (PNHR) ${ }^{13}$. PMCMV é operado com recursos do Fundo de Arrendamento Residencial (FAR), sistema segundo o qual o tomador do recurso e o agente produtor das unidades habitacionais é o setor empresarial; e o MCMV Entidades, operado com recursos do Fundo de Desenvolvimento Social (FDS). De acordo com esse sistema, o tomador do recurso e agente produtor das unidades habitacionais são as entidades sem fins lucrativos. Ressalta-se que, em todas as modalidades do PMCMV e nos dois subprogramas, o recurso se compõe, em parte, de subsídio, e em outra, de financiamento. O subsídio é sempre integral, no grupo de menor renda (Faixa 1), com recursos oriundos do Orçamento Geral da União (transferidos para o FAR e FDS), enquanto o financiamento da UH varia conforme a diferença de quanto foi subsidiado, e nas demais faixas de renda (Faixa 2 e 3), a fonte é o Fundo de Garantia do Tempo de Serviço (FGTS). Vale a pena recordar que, na concepção do PMCMV, as três faixas foram enquadradas como baixa renda e estavam atreladas ao salário mínimo. Algum tempo depois, sofreram uma alteração e os novos tetos foram fixados, com os limites para cada faixa estipulados com base na renda, mas não mais com relação ao salário mínimo. Muito embora o subsídio federal para a Faixa 2 seja bem menor, priorizando as famílias com menores rendas, da Faixa 1 (com subsídio praticamente integral), não significa que a Faixa 2 seja de mercado, muito pelo contrário, reconhecemos esse "perfil" de renda entre a demanda municipal $^{14}$.

O MCMV não deixa dúvidas de que "garantiu a continuidade de um novo patamar de acumulação na produção imobiliária residencial no Brasil” (MARICATO, 2012, 63) colocando em funcionamento um poderoso mecanismo de captura do fundo público (via subsídios) e da massa salarial (por financiamentos), na forma de renda fundiária (ROYER, 2009; FIX, 2011; BASTOS, 2012, BUONFIGLIO e BASTOS, 2011).

Contudo, nem tudo se perde da política anterior, original, ou norteadora de diretrizes e princípios (SNHIS), restando alguns elementos embrionários, sobretudo na definição da demanda da baixa renda, de acordo com os critérios de prioridade. Para tornar a demanda

\footnotetext{
${ }^{13}$ O Programa Nacional de Habitação Rural (PNHR) é voltado à população que vive no campo, como agricultores familiares, trabalhadores rurais, assentados do Programa Nacional de Reforma Agrária (PNRA), quilombolas, extrativistas, pescadores artesanais, ribeirinhos, indígenas e demais comunidades tradicionais.

${ }^{14}$ Houve uma grande parcela da demanda de baixa renda nos municípios que não foram atendidas pois auferiam renda mensal familiar acima do teto do Faixa 1, á época ( $\mathrm{R} \$ 1.600,00$ reais), mas, ao mesmo tempo, não podia pagar valores exigidos por imóveis na planta da modalidade Faixa 2, sobretudo com taxas de corretagem e entrega de chave. Portanto, a faixa de renda 2 é configurada como operação de mercado. Não à toa que no PMCMV 3, que não chegou a ser implantado, figurava a modalidade Faixa 1,5.
} 
solvável foi preciso um maciço investimento em subsídios para financiamento das famílias de baixa renda: no primeiro ano do MCMV (2009) foram investidos 14 bilhões de reais, valor que chegou a ser quadruplicado em 2012, quando atingiu a cifra de 57 bilhões, se retraindo no último ano, 2014, para 45 bilhões (Tabela 1; Gráfico 1), assim distribuídos pelas cinco regiões do país (Tabela 2; Gráfico 2a e 2b).

Tabela 1. Valor Total dos Investimentos anuais (R\$ bilhões) do PMCVM, Brasil (2009-2014)

\begin{tabular}{|c|c|}
\hline ANO & Investimento anual (R\$ bilhões) \\
\hline 2009 & $\mathrm{R} \$ 14.397,00$ \\
\hline 2010 & $\mathrm{R} \$ 39.504,00$ \\
\hline 2011 & $\mathrm{R} \$ 32.124,00$ \\
\hline 2012 & $\mathrm{R} \$ 57.392,00$ \\
\hline 2013 & $\mathrm{R} \$ 55.541,00$ \\
\hline 2014 & $\mathrm{R} \$ 45.320,00$ \\
\hline Total & $\mathrm{R} \$ 244.278,00$ \\
\hline
\end{tabular}

Fonte: Portal Brasileiro de Dados Abertos ${ }^{15}$

Elaboração BUONFIGLIO, L.V; OLIVEIRA, M.

Gráfico 1. Valor Total dos Investimentos anuais (R \$ bilhões) PMCVM, Brasil (2009-2014)

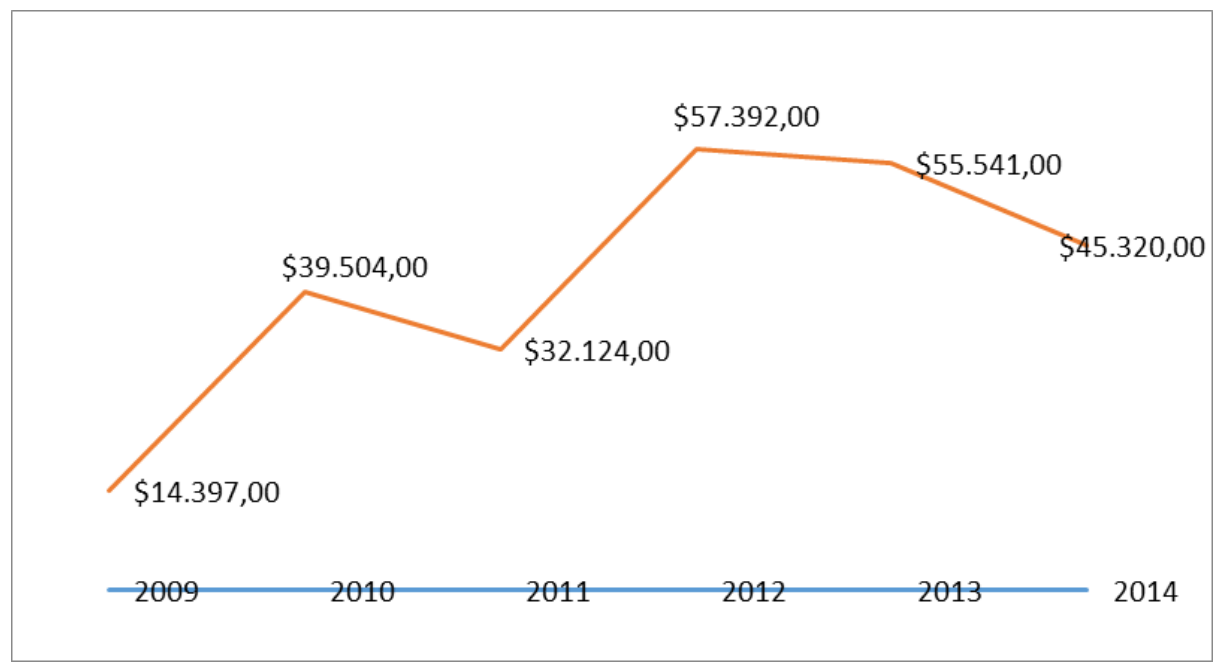

Fonte: Portal Brasileiro de Dados Abertos ${ }^{16}$

Elaboração BUONFIGLIO, L.V; OLIVEIRA, M.

15 http://dados.gov.br/dataset/minha-casa-minha-vida. Acesso em novembro de 2017.

16 http://dados.gov.br/dataset/minha-casa-minha-vida. Acesso em novembro de 2017. 
Tabela 2. Valor Total dos Investimentos anuais ( $\mathrm{R}$ bilhões) e porcentagens das operações do PMCVM por regiões, Brasil (2009-2014)

\begin{tabular}{|c|c|c|c|c|c|c|c|}
\hline \multirow{2}{*}{$\begin{array}{c}\text { Brasil - } \\
\text { Regiões }\end{array}$} & 2009 & 2010 & 2011 & 2012 & 2013 & 2014 & $\%$ \\
\cline { 2 - 8 } & 1,397 & 3,909 & 4,444 & 7,128 & 7,769 & 4,5 & $12 \%$ \\
\hline $\begin{array}{c}\text { Centro - } \\
\text { Oeste }\end{array}$ & 3,632 & 10,443 & 5,788 & 13,982 & 15,903 & 11,029 & $25 \%$ \\
\hline Nordeste & 0,588 & 2,523 & 1,856 & 3,379 & 4,262 & 2,278 & $6 \%$ \\
\hline Norte & 5,959 & 15,586 & 13,116 & 22,921 & 18,168 & 17,319 & $38 \%$ \\
\hline Sudeste & 2,821 & 7,043 & 6,92 & 9,982 & 9,439 & 10,194 & $19 \%$ \\
\hline Sul & $\mathbf{1 4 , 3 9 7}$ & $\mathbf{3 9 , 5 0 4}$ & $\mathbf{3 2 , 1 2 4}$ & $\mathbf{5 7 , 3 9 2}$ & $\mathbf{5 5 , 5 4 1}$ & $\mathbf{4 5 , 3 2}$ & $\mathbf{1 0 0 \%}$ \\
\hline $\begin{array}{c}\text { Totais } \\
\text { Total investido no }\end{array}$ & \multicolumn{7}{|c|}{$\mathbf{2 4 4 , 2 7 8}$} \\
\hline \\
período de 2009 a 2014
\end{tabular}

Fonte: Portal Brasileiro de Dados Abertos ${ }^{17}$

Elaboração BUONFIGLIO, L.V; OLIVEIRA, M.

Gráfico 2a. Valor Total dos Investimentos (R \$ bilhões) do PMCVM por regiões, Brasil (2009-2014)

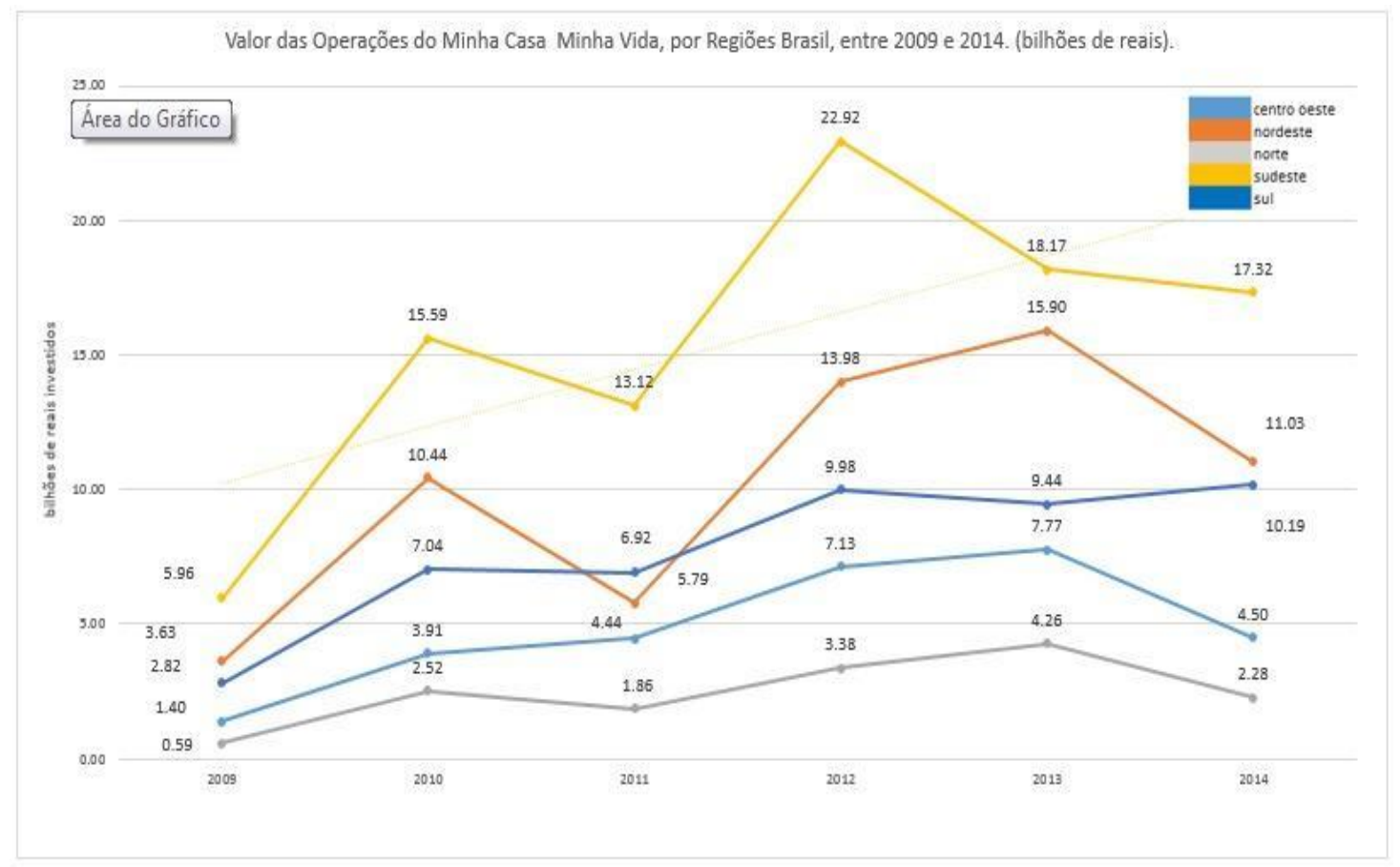

Fonte: Portal Brasileiro de Dados Abertos ${ }^{18}$

Elaboração BUONFIGLIO, L.V; OLIVEIRA, M.

17 http://dados.gov.br/dataset/minha-casa-minha-vida. Acesso em novembro de 2017.

18 http://dados.gov.br/dataset/minha-casa-minha-vida. Acesso em novembro de 2017. 
Gráfico 2b. Porcentagens dos Investimentos (R\$ bilhões) do PMCVM por regiões, Brasil (2009-2014)

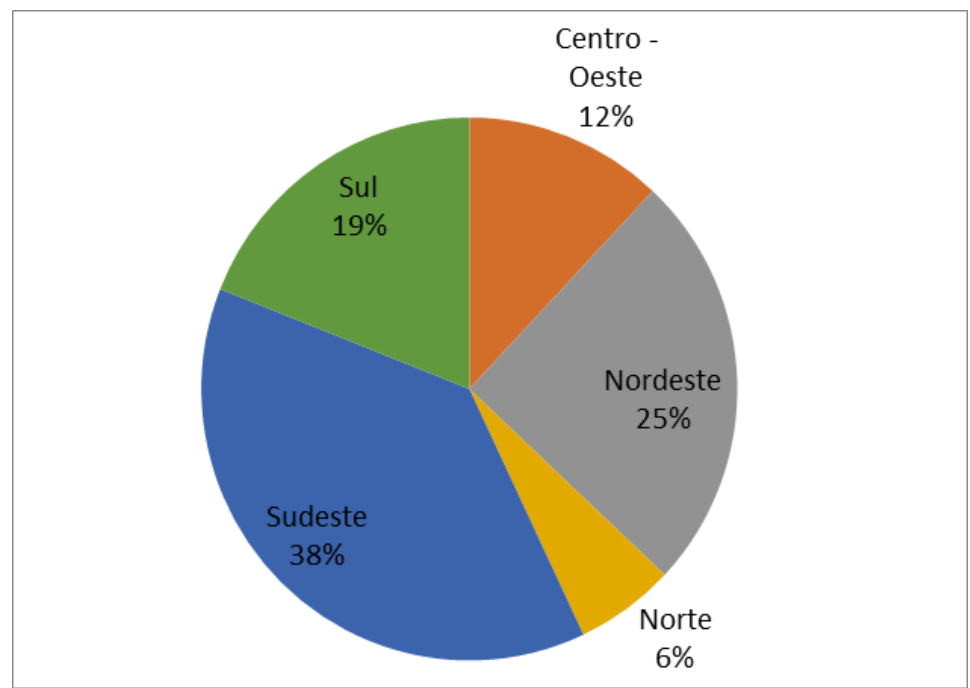

Fonte: Portal Brasileiro de Dados Abertos ${ }^{19}$.Elaboração BUONFIGLIO, L.V; OLIVEIRA, M.

Ao longo do tempo, o programa foi acumulando uma série de críticas, apontadas em diversas produções recentes (ROYER, 2009; SHIMBO, 2010; FIX, 2011; LAGO, 2011). O ponto de partida de algumas dessas pesquisas se atém, sobretudo, à dimensão econômica e política do espaço urbano brasileiro, na medida em que as recentes transformações nesse espaço estão profundamente relacionadas com o último episódio de crise internacional, que abalou os mercados mundiais em diversos países. O período da crise, originada no mercado de hipotecas dos EUA (FIX, 2011), por sua vez, coincide com a intensificação dos processos de financeirização imobiliária num período bem preciso. Uma crescente entrada de capital internacional no mercado nacional de produção habitacional foi registrada entre 2006 e $2008^{20}$, quando as principais incorporadoras imobiliárias e empresas com atuação no ramo imobiliário brasileiro venderam títulos e ações nas bolsas de valores. O Brasil entrava, de vez, na financeirização da habitação.

A capitalização nas bolsas de valores possibilitou a ampliação e a expansão dos estoques de terra das principais empresas e fundos de investimento, que atuam com a incorporação e construção de unidades habitacionais, aumentando a capacidade desses

\footnotetext{
19 http://dados.gov.br/dataset/minha-casa-minha-vida. Acesso em novembro de 2017.

${ }^{20}$ Em 2007, a renda variável captada no mercado de títulos e ações pelo setor imobiliário já chegava a R 12 bilhões, possibilitando grandes investimentos na aquisição de estoques de terras e ampliação da atuação dessas empresas para outras cidades. (BUONFIGLIO e BASTOS, 2011).
} 
agentes de pagar pela terra e provocando efeitos de retenção especulativa da propriedade imobiliária nas cidades (BUONFIGLIO e BASTOS, 2011).

Para contornar a crise internacional de superacumulação de 2008, o Brasil lançou, em 2009, o Programa Minha Casa, Minha Vida, encarado como "pacote de investimentos lucrativos" onde alocar excedentes de capitais para as construtoras, incorporadoras e empresas imobiliárias, nas cidades brasileiras, que serviu de "para-raios" da crise internacional, fazendo disparar o crescimento da economia nacional no setor da construção civil, ampliando o mercado, aumentando a demanda por materiais de construção, não sem reelaborar ideologicamente a propaganda da casa própria, permitindo, porém, a ampliação do crédito e da oferta da mercadoria habitação às camadas mais pobres da população.

Assim o PMCMV operava simultaneamente todas as categorias da habitação, como necessidade, demanda, mercadoria, déficit e política pública, contudo:

De meta objetiva das políticas do setor, o 'combate ao déficit' (...) tem sido utilizado como pretexto para a criação de novos instrumentos de crédito, mais vocacionados à acumulação financeira de capital que à universalização do direito à moradia. Este fenômeno, evidentemente, não é uma exclusividade brasileira. Reflete, na verdade, o movimento de financeirização do crédito imobiliário, dentro do qual a habitação figura, na maior parte das vezes, meramente como pretexto. (ROYER, 2009 p. 21).

À parte a questão da prioridade para baixa renda, a Lei no 11.124/05 sinalizava "quotas para idosos, deficientes e famílias chefiadas por mulheres", que são atualmente alguns dos critérios de prioridade para a demanda municipal do MCMV Faixa 1.

Em 2010, o Governo Federal anunciou a transferência de recursos do Fundo Nacional de Habitação de Interesse Social (FNHIS) para entidades civis sem fins lucrativos, operacionalizado por contratos de repasse assinados entre a CEF e as entidades. No mesmo ano, a Portaria $n^{\circ} 618$ (14/12/2010) estabeleceu os critérios de participação e seleção, no processo seletivo, de entidades privadas sem fins lucrativos, com vistas à indicação de beneficiários para os imóveis oriundos do Fundo do Regime Geral da Previdência Social (FRGPS) destinados ao PMCMV. Surgia a "modalidade" MCMV Entidades, com recursos do Fundo de Desenvolvimento Social (FDS), mesma fonte de financiamento do anterior Programa Crédito Solidário, criado em 2004 pela Secretaria Nacional da Habitação do Ministério das Cidades. 
A participação e o acesso de novos agentes (entidades sociais) aos recursos orçamentários revelam uma dimensão da descentralização da política habitacional, como estava embrionariamente na Lei $\mathrm{n}^{\circ}$ 11.124/05. O MCMV Entidades também aprofunda o debate da gestão (retomando o papel do Estado e demais agentes sociais na produção e apropriação do espaço incluindo novos agentes não restritos ao mercado na esteira do processo). Porém, ainda assim, o PMCMV contrariou as expectativas de criação de arenas de luta como conselhos populares locais como no modelo do SNHIS/FNHIS, porque se desenvolve numa negociação política interna (ao órgão gestor específico para tratar a política habitacional ou até mesmo em outra secretaria, gabinete do prefeito, gerência da Caixa Econômica Federal etc., quando o município não se vale dessa estrutura), em uma esfera restrita à estatal/institucional, não pública, mas mediada pelo poder público diretamente em negociação com os "parceiros da produção espacial”, sejam eles empresários e demais agentes da construção civil (em quantidade muito superior), sejam eles entidades sociais (em muito menor quantidade).

\section{DA LEITURA DO DÉFICIT QUALITATIVO À URBANIZAÇÃO DE ASSENTAMENTOS: O PROGRAMA PAC-UAP}

A classificação e hierarquização das cidades, pelo déficit meramente quantitativo, justificou uma política de escala que deu o sentido político e discursivo (e também ideológico ao PMCMV). Já a categoria socioespacial assentamentos precários revelou o déficit qualitativo, encaixando-se perfeitamente ao Programa PAC - Urbanização de Assentamentos Precários, como fica nítido na fala institucional a seguir:

O Brasil responde criando dois grandes programas habitacionais de interesse social: urbanização de assentamentos precários e produção habitacional em escala. A política de HIS cumpre o duplo objetivo de prover condições adequadas de moradia para a população de baixa renda e de gerar emprego e renda, dinamizando a economia. É preciso suprir o déficit habitacional e, ao mesmo tempo, fazer frente ao crescimento populacional. Os países em desenvolvimento estão em construção e carecem de infraestrutura. Temos o desafio de produzir, com sustentabilidade, milhões de moradias, quebrando paradigmas e construindo cidades. (Apresentação gestora Júnia Santa Rosa no Fórum dos Gestores Municipais do RS, em 16/05/2014).

A despeito dos interesses capitalistas que demandam a criação de tais Programas, é inegável que tais processos vincularam o Ministério das Cidades a expressivos recursos da União: 
Com o Ministério (...) o setor habitacional e a área de habitação de interesse social e o setor habitacional de mercado passaram a se articular com eixos importantes da política de desenvolvimento urbano no país. A inclusão da urbanização de assentamentos precários no eixo de infraestrutura social e urbana do PAC trouxe importantes avanços na consolidação de uma estratégia nacional para garantir moradia digna para famílias de baixa renda. (VIERA e CHAVES, 2011, p.100).

Cabe destacar que a MUNIC de 2004 já registrava que os programas "urbanização de assentamentos" apareciam em proporções mais elevadas nos municípios mais populosos. No grupo das cidades com mais de 500.000 habitantes, por exemplo, 94,1\% das prefeituras executaram ações com vistas à urbanização de assentamentos ao longo daquela gestão. Isso revela que a urbanização de assentamentos já era uma linha de ação importante nos municípios, no ano de 2004, em que a gestão municipal se encerrava (2000-2004) e a gestão do Ministério das Cidades tinha início (segundo ano). Portanto, mesmo que essa ação tenha se consolidado como um importante programa federal, posteriormente (a partir do PAC, 2007) como vetor de indução da escala federal à escala municipal, atingindo não apenas municípios maiores, cabe destacar que, como linha de ação, surge na instância da gestão municipal.

De fato, a categoria assentamentos precários abarca inúmeras carências e inadequações urbanas, como um amálgama de precariedades que se caracteriza por múltiplos aspectos:

irregularidade fundiária e/ou urbanística; pela deficiência da infraestrutura; pela ocupação de áreas sujeitas a alagamentos, deslizamentos ou outros tipos de risco; pelos altos níveis de densidade dos assentamentos e das edificações combinados à precariedade construtiva das unidades habitacionais; pelas grandes distâncias percorridas entre a moradia e o trabalho associadas a sistemas de transportes insuficientes, caros e com alto nível de desconforto e insegurança; além da insuficiência dos serviços públicos em geral, principalmente os de saneamento, educação e saúde. (VIERA e CHAVES, 2011, p. 101).

Seu objetivo apresenta uma justificativa mais próxima da busca pelo direito à moradia digna e direito à cidade, pela inserção e integração com a malha urbana existentes dialogando mais com o desenvolvimento urbano (MARICATO, 2012). ${ }^{21}$ Como Programa nacional, priorizou a seleção de projetos incidentes em grandes complexos de favelas, palafitas, comunidades próximas, ou sobre mananciais e áreas de risco iminente. Assim, a estratégia

\footnotetext{
${ }^{21}$ De fato, a autora constata que no PAC 1, de 2007, anterior ao MCMV, a maior parte dos recursos se direcionam à moradia e infraestrutura social para urbanização de favelas.
} 
consistiu em focar "nas principais cidades do país", com intervenções "que exigiram maior volume de recursos e com grande complexidade de execução". As primeiras seleções ocorreram no início de 2007 e, posteriormente, passaram a ocorrer anualmente, já abrangendo assentamentos precários de menor porte. O PAC consolidou um desenho propositivo, no qual o município priorizava a intervenção e concorria a uma seleção anual podendo ter chance de se organizar para concorrer no ano seguinte.

Em 2011 havia, ainda, o atrelamento dessas políticas; MCMV Entidades e PAC UAP subsidiadas com parte dos recursos do FNHIS, como demonstra o Quadro 2, a seguir.

Quadro 2 - PAC: Programas, Ações e Fontes de Recursos

\begin{tabular}{|c|c|c|c|}
\hline \multicolumn{4}{|c|}{ Programas e ações sob responsabilidade do DUAP1 } \\
\hline Fonte & Programa & Ação & $\begin{array}{c}\text { Agente } \\
\text { operador }\end{array}$ \\
\hline \multirow[b]{2}{*}{ FNHIS $^{2}$} & Habitação de interesse social & $\begin{array}{l}\text { Apoio à provisão habitacional de } \\
\text { interesse social }\end{array}$ & \multirow{6}{*}{$\mathrm{CEF}$} \\
\hline & $\begin{array}{l}\text { Urbanização, Regularização e } \\
\text { integração de Assentamentos } \\
\text { precários }\end{array}$ & $\begin{array}{l}\text { Apoio à melhoria das condições de } \\
\text { habitabilidade de assentamentos } \\
\text { precários }\end{array}$ & \\
\hline OGU Repasse & $\begin{array}{l}\text { Projetos prioritários de } \\
\text { investimentos - PPI intervenções em } \\
\text { favelas }\end{array}$ & $\begin{array}{l}\text { Apoio à melhoria das condições de } \\
\text { habitabilidade de assentamentos } \\
\text { precários }\end{array}$ & \\
\hline \multirow{3}{*}{$\begin{array}{l}\text { FGTS } \\
\text { Financiamento }\end{array}$} & \multirow{3}{*}{$\begin{array}{l}\text { Programa de Atendimento } \\
\text { habitacional pelo poder público - } \\
\text { Pró-Moradia }\end{array}$} & $\begin{array}{l}\text { Urbanização e regularização de } \\
\text { assentamentos precários }\end{array}$ & \\
\hline & & Produção de Conjuntos habitacionais & \\
\hline & & Desenvolvimento institucional & \\
\hline $\begin{array}{l}\text { FAT } \\
\text { Financiamento }\end{array}$ & Projetos multissetoriais integrados & $\begin{array}{l}\text { Urbanização e regularização de } \\
\text { assentamentos precários }\end{array}$ & BNDS \\
\hline
\end{tabular}

Fonte: BUONFIGLIO, L. V. (2015).

De acordo com E. Maricato (2012), os investimentos do PAC para habitação eram da ordem de 106,3 bilhões de reais. Destes, 11,6 bilhões foram para a urbanização de favelas e 44, 3 bilhões para novas moradias. Já os dados indicados posteriormente pela Secretária de Habitação do Ministério das Cidades, apontam que para, o PAC UAP e PAC Saneamento foram alocados quase R \$ 29 bilhões em intervenções (MAGALHÃES, 2013), sendo que, até 2011, R\$ 2,8 bilhões eram oriundos do FNHIS (VIERA e CHAVES, 2011). 


\section{CONSIDERAÇÕES FINAIS}

Recuperando o contexto da política brasileira de habitação da última década (2005 2015) nota-se claramente os efeitos da criação de um ambiente institucional e de um marco jurídico-regulatório no contexto do país que de fato, alçaram a habitação de interesse social na pauta dos temas prioritários em nível nacional. A preocupação dos gestores da política urbana nos primeiros anos do Ministério das Cidades quanto às estratégias de indução e de coordenação nacional das políticas urbanas no arranjo federativo trinitário existente se traduziu na proposta de montagem do Sistema Nacional de Habitação de Interesse Social, o SNHIS. Concebido como diretriz de planejamento da política macro urbana do país, tal sistema levava em conta os três níveis federativos num rearranjo da política urbana que aprofundou a gestão institucional, retomando o papel do Estado e demais agentes sociais na produção da política. Tal sistema descentralizava recursos de um fundo nacional específico, o FNHIS (reivindicação histórica popular) de acordo com programas, projetos e necessidades municipais mediante a adequação institucional, pela criação de esferas públicas locais não estritamente estatais (como as arenas instituídas por conselhos paritários e aqueles com maior representação da sociedade civil, sobretudo), para a elaboração e execução de políticas municipais. Contudo, em que pese todo o esforço de implantação de uma Política Nacional de Habitação de Interesse Social pelo SNHIS/FNHIS, ela não se efetivou.

A leitura das cidades pelo déficit habitacional quantitativo e qualitativo orientou tecnicamente a política urbana habitacional e acabou por dar o sentido social e discursivo à política de escala do PMCMV e do PAC- UAP. Isso é, tais Programas Nacionais, diferente do SNHIS, não nasceram do Ministério das Cidades, mas no bojo da produção da política econômica macroestruturante do país, tendo sido incorporados à pasta da política urbana habitacional, tornando-se funcionais à própria produção da política social já que incorporaram as diretrizes básicas (como a reorientação dos subsídios para a baixa renda que haviam sido estabelecidas anteriormente com o SNHIS). O Programa Minha Casa, Minha Vida tomou o rumo da produção do espaço deliberadamente como política econômica, ainda que tenha possibilitado o enquadramento e atendimento da baixa renda com subsídios federais que permitiram tornar a demanda solvável chancelando uma política social. A produção maciça de empreendimentos habitacionais e a intervenção em assentamentos precários deram vazão ao circuito produtivo da economia capitalista da cidade justificadas pelo déficit habitacional. A 
alocação de fartos recursos nesses dois Programas, desatrelados ao FNHIS, tiraram a força política deste e o fundo histórico minguou.

A política urbana habitacional brasileira da última década atesta também as complexas relações de força no interior dos aparelhos estatais; os intermitentes caminhos da política pública e a intensa disputa de arenas de luta. Se o SNHIS/FNHIS provocou o empenho das gestões municipais no sentido de criação de novas esferas de poder não exclusivamente estatais como Conselhos Locais dotados de Fundo e a consecução do PLHIS como indicador e orientador do déficit municipal, o PMCMV e o PAC desestimulam tais processos já que as modalidades a serem implantadas não dependem de uma definição por essas estruturas e nem precisam captar recursos para seu fundo já que há uma fonte mais segura (pela escala federal) e o déficit que valia para o PMCMV era aquele apontado por instâncias nacionais bem como o número máximo de unidades habitacionais a serem construídas, isto é, não dependeu do apontamento do diagnóstico do Plano Local, mas de outro déficit amplo e genérico do IBGE.

Da mesma forma, o SNHIS/FNHIS provocou um processo de institucionalização de órgãos e estruturas para dar conta do tratamento da política habitacional, o que não se verifica para o Programa Minha Casa, Minha Vida, cuja massificação Brasil adentro permite analisar a replicação de projetos e empreendimentos de gabinete, chancelado num processo nada democrático e arbitrário, de pouca transparência entre prefeitos, vereadores e empresários vendedores de projetos à revelia do planejamento urbano territorial.

De toda forma, conclui-se uma reorientação da política urbana e habitacional da década analisada com a redefinição de atribuições dos entes federados e nova articulação das esferas de poder: ainda que tenha havido uma tentativa de redistribuição do planejamento e gestão entre as três escalas administrativas e políticas. Ao fim e ao cabo, o resultado foi a indução da escala federal e a gestão na escala municipal. Essa reorientação reforçou as escalas federal e municipal e enfraqueceu a escala estadual que oscila entre uma instância intermediária, dentro de uma relação polarizada pelas esferas nacional e municipal. Tais conclusões trazem resultados importantes para a Geografia porque fornecem um novo quadro de análise para a compreensão dos contornos móveis e instáveis das esferas onde são alocados poderes, atribuições e compromissos "refuncionalizando" uma escala em detrimento de outra. Para a Geografia é relevante também apontar os níveis de regulação da política pública habitacional; enquanto na instância federal estão a diretriz genérica e a fonte de subsídios federais, no município, estão as demais condições para o rebatimento e enraizamento de uma 
política que é espacial e fundiária deixando patente a contradição da produção da política e da produção do espaço.

\section{REFERENCIAS BIBLIOGRÁFICAS}

ARRETCHE, Marta. Federalismo e Políticas Sociais no Brasil - problemas de coordenação e autonomia. São Paulo em Perspectiva, Fundação Seade, São Paulo, v. 18, n. 2, p. 17-26, 2004.

Federalismo e Relações Intergovernamentais no Brasil: A Reforma de Programas Sociais. DADOS - Revista de Ciências Sociais, Rio de Janeiro, v. 45, n. 3, p. 431-458, 2002b.

Financiamento federal e gestão local de políticas sociais: o difícil equilíbrio entre regulação, responsabilidade e autonomia. Ciência \& Saúde Coletiva, ABRASCO, Rio de Janeiro, v. 8, n. 2, p. 331-345, 2003.

Políticas Sociais no Brasil: Descentralização em um estado federativo. Artigo de 1996. Anais... XXI Encontro da LASA, Chicago, USA, 24-26 de setembro de 1998.

. Relações Federativas nas Políticas Sociais. Educ. Soc., Campinas, v. 23, n. 80, p. 25 48, setembro 2002a. Disponível em: <http://www.cedes.unicamp.br>. Acesso em: 12/04/2013.

BOLAFFI, Gabriel. O problema e o falso problema. In: MARICATO, E. (Org.). A produção capitalista da casa e da cidade no Brasil. São Paulo: MFA-Ômega, 1992.

BONDUKI, Nabil. Avanços, Limitações e Desafios da Política Habitacional do Governo Lula - Direito à Habitação em oposição ao direito à cidade. In: FERNANDES, Edésio; ALFONSIN, Betânia. (Coords.). Direito à Moradia Adequada: o que é, para quem serve, como defender e efetivar. Belo Horizonte: Fórum, 2014. p. 293-316.

(Org.). Planos Locais de Habitação: das origens aos dilemas atuais nas regiões metropolitanas. In: DENALDI. R. Planejamento Habitacional. Notas sobre a precariedade e terra nos planos locais de Habitação. São Paulo: Annablume, 2013.

BRANDÃO, Carlos. Sobre Desenvolvimento, Planejamento e Desafios para a Pactuação Multiescalar no Federalismo Brasileiro. In: MONTEIRO NETO, Aristides. (Org.). Governos Estaduais no Federalismo Brasileiro. Capacidades e Limitações Governativas em Debate. Brasília: IPEA, 2014. p. 213-232.

BRASIL. Ministério das Cidades. Gabinete do Ministro. Portaria n⿳ 618, de 14 de dezembro de 2010. Dispõe sobre o processo de seleção de Entidades Privadas sem Fins Lucrativos, com vistas à indicação de beneficiários para os imóveis oriundos do Fundo do Regime Geral de Previdência Social destinados ao Programa Minha Casa Minha Vida. Brasília: D.O.U., 16.12.2010.

Ministério das Cidades. Secretaria Nacional de Habitação. Plano Nacional de Habitação - PlanHab. Brasília: MC/SNH, 14.12.2010.

Presidência da República. Casa Civil. Subchefia para Assuntos Jurídicos.

Constituição da República Federativa do Brasil de 1988. Brasília: 5 out. 1988.

Presidência da República. Casa Civil. Subchefia para Assuntos Jurídicos. Emenda

Constitucional $\mathbf{n}^{\mathbf{0}}$ 26, de 14 de fevereiro de 2000. Altera a redação do art. $6^{\circ}$ da Constituição Federal. Brasília: D.O.U., 15.2.2000. 
Presidência da República. Casa Civil. Subchefia para Assuntos Jurídicos. Lei no 11.124, de 16 de junho de 2005. Dispõe sobre o Sistema Nacional de Habitação de Interesse Social - SNHIS, cria o Fundo Nacional de Habitação de Interesse Social - FNHIS e institui o Conselho Gestor do FNHIS. Brasília: D.O.U., 17.6.2005.

BUONFIGLIO, Leda V.; BASTOS, Rodrigo D. O lugar das políticas de habitação popular nas cidades brasileiras. Anais... XII SIMPOSIO NACIONAL DE GEOGRAFIA URBANASIMPURB, Belo Horizonte, 16 a 19 de novembro de 2011.

BUONFIGLIO, Leda V. O Resgate do centro de Porto Alegre: a luta dos sem-teto pelo direito à moradia. Dissertação (Mestrado em Geografia) - Departamento de Geografia. Universidade de Brasília. Brasília: UnB, 2007. 239 f.

CAPEL, Horácio. La Morfología de las Ciudades. II Aedes Facere: técnica, cultura y clase social em la construcción de edifícios. Barcelona: Ediciones Del Serbal, 2005.

CASTRO, Iná Elias. Geografia e Política. Territórios, Escalas de Ação e Instituição. Rio de Janeiro: Bertrand, 2005.

DAVIS, Mike. Planeta Favela. São Paulo: Boitempo, 2006.

DENALDI, Rosana. Planejamento Habitacional: Notas sobre a precariedade e terra nos Planos Locais de Habitação. São Paulo: Annablume, 2013.

ENGELS, Friedrich. Situação da Classe Trabalhadora em Inglaterra. São Paulo: Boitempo, 2011.

FIX, Mariana de Azevedo Barreto. Financeirização e Transformações Recentes no Circuito Imobiliário no Brasil. Tese (Doutorado em Economia) - Instituto de Economia. Universidade Estadual de Campinas. Campinas: UNICAMP, 2011. $288 \mathrm{f}$.

IBGE. Instituto Brasileiro de Geografia e Estatística. Aglomerados subnormais. Primeiros resultados. Censo Demográfico 2010. Rio de Janeiro: IBGE , 21 de dezembro de 2011.

(Versão digital).

ISMAEL, Ricardo. Governos Estaduais no Ambiente Federativo Inaugurado pela Constituição Federal de 1988: Aspectos Políticos e Institucionais de uma Atuação Constrangida. In: IPEA. Governos Estaduais no Federalismo Brasileiro. Capacidades e Limitações Governativas em Debate. Brasília: IPEA, 2014.

LAGO, Luciana Correa do. Autogestão na superação da periferia urbana: conflitos e avanços. Revista Eletrônica de Estudos Urbanos e Regionais,[online], n. 05, ano 02, junho de 2011. LIMONAD, Ester. Da política à não política e a ingovernabilidade do território. In: PAES, M. T. D; SILVA, C. A. da; MATIAS, L. F. (Orgs.). Geografias, Políticas Públicas e Dinâmicas Territoriais. Dourados-MS: Ed. UFGD, 2013. 266 p. (Publicação em e-book).

MAGALHAES, Inês. Planos Locais de Habitação na estratégia da Política Nacional. In: DENALDI. Rosana. Planejamento Habitacional: notas sobre a precariedade e terra nos Planos Locais de Habitação. São Paulo: Annablume 2013. p. 13-27.

MARICATO, Ermínia. O impasse da política urbana no Brasil. 2. ed. Petrópolis: Vozes, 2012.

NASCIMENTO DOS SANTOS, Renato Emerson. Movimentos Sociais e Geografia: Sobre a(s) espacialidade(s) da ação social. Rio de Janeiro: Consequência, 2011.

ROYER, Luciana de Oliveira. Financeirização da política habitacional: limites e perspectivas. São Paulo: USP/Faculdade de Arquitetura e Urbanismo, 2009.

SHIMBO, Lúcia Zanin. Habitação Social, Habitação de mercado: a confluência entre Estado, empresas construtoras e capital financeiro. Tese (Doutorado em Engenharia) Universidade de São Paulo. São Carlos: USP, 2010.

VALENÇA. Márcio Moraes. Anotações Críticas acerca da política Habitacional Brasileira. In: FERNANDES, Edésio; ALFONSIN, Betânia. (Coords.). Direito à Moradia Adequada - 
o que é, para quem serve, como defender e efetivar. Belo Horizonte: Fórum, 2014. p.341354

VIERA, Alessandra de; CHAVES, Mirna Q. B. Política Nacional de Habitação: programas e resultados. In: FARIA, Rodrigo de; SCHWASBERG, Benny. (Orgs.). Políticas Urbanas e Regionais no Brasil. Brasília: Universidade de Brasília/Faculdade de Arquitetura e Urbanismo, 2011.

Recebido em 18 de junho de 2017.

Aceito em 12 de dezembro de 2017. 